\title{
Water stress before harvest of pepper-rosmarin
}

\author{
Ivan Caldeira Almeida Alvarenga(1), Rafael Vasconcelos Valadares(2), Ernane Ronie Martins ${ }^{(2)}$, \\ Flávio Gonçalves Oliveira( ${ }^{(2)}$, Lourdes Silva de Figueiredo ${ }^{(2)}$ and Mauro Koji Kobayashi( ${ }^{(3)}$
}

\begin{abstract}
(1)Universidade Federal de Lavras, Departamento de Agricultura, Caixa Postal 3037, CEP 37200-000 Lavras, MG, Brazil. E-mail: pytchouai@yahoo.com.br (2)Universidade Federal de Minas Gerais, Campus Montes Claros, Instituto de Ciências Agrárias, Avenida Universitária, № 1.000, Bairro Universitário, CEP 39404-000 Montes Claros, MG, Brazil. E-mail: rafaelvvaladares@hotmail.com, ernane_martins@oi.com.br, flaviogoliveira@ibest.com.br, lourdes.figueiredo@oi.com.br (3)Universidade Estadual de Montes Claros, Centro de Ciências Agrárias, Rua Reinaldo Viana, oo 2.630, Bairro Bico da Pedra, CEP 39440-000 Janaúba, MG, Brazil.

E-mail: mauro.koji@unimontes.br
\end{abstract}

\begin{abstract}
The objective of this work was to assess the effect of different periods of water stress before harvest of pepper-rosmarin (Lippia sidoides) on the contents of essential oil and flavonoids. The experiment was carried out during 270 days of cultivation, with drainage lysimeters, in a completely randomized block design with five treatments: $0,2,4,6$, and 8 days of water suppression before harvest, with four replicates. Fresh and dry matter yield, essential oil content, total flavonoids content, and water potential and temperature of leaves were determined. There was a decrease of approximately $50 \%$ in oil content and of $60 \%$ in total flavonoid content with the reduction of leaf water potential in $0.3 \mathrm{MPa}$. Essential oil is more sensitive to water stress than total flavonoids.
\end{abstract}

Index terms: Lippia sidoides, essential oil, flavonoids, leaf water potential, medicinal plant, water stress.

\section{Estresse hídrico antes da colheita de alecrim-pimenta}

Resumo - O objetivo deste trabalho foi avaliar o efeito de diferentes períodos de estresse hídrico antes da colheita de alecrim-pimenta (Lippia sidoides) sobre o conteúdo de óleo essencial e de flavonoides. O experimento foi realizado durante 270 dias de cultivo, com lisímetros de drenagem, em delineamento inteiramente casualizado, com cinco tratamentos: 0, 2, 4, 6 e 8 dias de supressão de irrigação antes da colheita, com quatro repetições. Foram determinados produção de matéria fresca e seca, teor de óleo essencial, teor de flavonoides totais, tensão e temperatura de folhas. Observou-se decréscimo de aproximadamente $50 \%$ no teor de óleo e de $60 \%$ no teor de flavonoides totais, com a diminuição do potencial hídrico foliar em $0,3 \mathrm{MPa}$. O óleo essencial é mais sensível ao estresse hídrico do que os flavonoides totais.

Termos para indexação: Lippia sidoides, óleo essencial, flavonoides, potencial hídrico foliar, planta medicinal, estresse hídrico.

\section{Introduction}

Pepper-rosmarin (Lippia sidoides Cham.) is an aromatic and medicinal species originated from the Brazilian Northeast and the semiarid regions of northern Minas Gerais state, Brazil. It is used to combat fungal infections, mouth inflammation, scabies, and bad odors of feet and armpits. Its essential oil, composed of a mixture of thymol and carvacrol, has antimicrobial properties against fungi and bacteria, and is effective in controlling Aedes aegypti larvae (Carvalho et al., 2003).

The behavior of medicinal plants is greatly influenced by water deficits, in terms of the production and the formation of compounds, such as alkaloids, flavonoids, parthenolides, and essential oils (Penka, 1978; Carvalho et al., 2003b; Castro et al., 2004; Bortolo et al., 2009). The level and duration of stress are fundamental in the response of aromatic and medicinal plants in terms of plant quality (Charles et al., 1990; Morvant et al., 1998). However, studies on the irrigated cultivation of these species are incipient, and plant behavior under stress conditions still needs further investigation (Carvalho et al., 2003a; Alvarenga et al., 2009).

Abiotic factors, such as temperature, cultivation season, time of harvest, and water availability, strongly influence medicinal plants. Therefore, studies related to this interaction are important to obtain information on the most appropriate irrigation management for the production of compounds of interest (Barros et al., 2009; Morais, 2009). 
The objective of this work was to evaluate the effect of different periods of water stress before harvest of pepper-rosmarin on the contents of essential oil and flavonoids.

\section{Materials and Methods}

The experiment was carried out at the experimental site of Instituto de Ciências Agrárias of Universidade Federal de Minas Gerais, located at Montes Claros, MG, Brazil $\left(16^{\circ} 44^{\prime} 02^{\prime \prime S}, 43^{\circ} 51^{\prime} 23^{\prime \prime} \mathrm{W}\right.$, at $646 \mathrm{~m}$ of altitude). The climate is classified as Aw, semiarid tropical savanna with dry winter and rainy summer, according to Köppen (Leite et al., 2004).

The experiment was carried out with drainage lysimeters in a Red Oxisol (Santos et al., 2006), with the following characteristics: $\mathrm{pH} \quad\left(\mathrm{H}_{2} \mathrm{O}\right)$, $5.9 ; 2.4 \mathrm{cmol}_{\mathrm{c}} \mathrm{dm}^{-3}$ of $\mathrm{Ca}^{2+} ; 1.0 \mathrm{cmol}_{\mathrm{c}} \mathrm{dm}^{-3}$ of $\mathrm{Mg}$; $6.72 \mathrm{mg} \mathrm{kg}^{-1}$ of $\mathrm{P}$ Mehlich; $18.78 \mathrm{mg} \mathrm{L}^{-1}$ of Prem; $90 \mathrm{mg} \mathrm{kg}^{-1}$ of K; $1.4 \mathrm{cmol}_{\mathrm{c}} \mathrm{dm}^{-3}$ of Al; $4.04 \mathrm{cmol}_{\mathrm{c}} \mathrm{dm}^{-3}$ of $\mathrm{H}+\mathrm{Al}$; sum of bases of $3.63 \mathrm{cmol}_{\mathrm{c}} \mathrm{dm}^{-3}$; base saturation of $47 \% ; 11.7 \mathrm{~g} \mathrm{~kg}^{-1}$ of organic matter; $45 \mathrm{~g} \mathrm{~kg}^{-1}$ of coarse sand; $355 \mathrm{~g} \mathrm{~kg}^{-1}$ of fine sand; $300 \mathrm{~g} \mathrm{~kg}^{-1}$ of silt; $300 \mathrm{~g} \mathrm{~kg}^{-1}$ of clay.

The growing period occurred from 9/15/2009 to $6 / 11 / 2010$, totaling 270 days of cultivation. Plants were derived from regrowth of plants pruned at 120 days after transplanting, and the seedlings were produced with cuttings. Treatments consisted of different periods of water suppression before harvest: T1, 0; T2, 2; T3, 4; T4, 6; and T5, 8 days without irrigation. A completely randomized block design, with four replicates, was used. At 95 days of cultivation, a supplemental fertilization of $12 \mathrm{~kg} \mathrm{~m}^{-2}$ of cattle manure was applied (Assis et al., 2009). Before the beginning of the treatments, plants were characterized as to height and crown and stem diameter, measured at $5 \mathrm{~cm}$ above soil, using graduated tape and digital caliper, respectively. Plants were grown in row spacing of $0.4 \times 0.4 \mathrm{~m}$, with nine plants per lysimeter.

At the beginning of the experiment, the soil at the bottom of the lysimeters was saturated and kept at field capacity until irrigation suppression. However, the total water volume consumed by the culture could not be determined, since there was no coverage in the area and, when the rainy season started, it was not possible to determine the percolated blade. Irrigation was carried out based on the reference evapotranspiration (ETo) calculated according to the Hargreaves-Samani equation:
$\mathrm{Et}_{\mathrm{o}}=\left[(\mathrm{Tmed}+17.8) \times 0.0023 \times \mathrm{Q}_{0}(\mathrm{Tmax}-\mathrm{Tmin})^{0.5}\right]$,

in which Eto is the potential evapotranspiration in millimiters per day; Tmed is the average daily temperature in ${ }^{\circ} \mathrm{C}$; Tmax is the daily maximum temperature in ${ }^{\circ} \mathrm{C}$; Tmin is the daily minimum temperature in ${ }^{\circ} \mathrm{C}$; $\mathrm{Q}_{\mathrm{o}}$ is the incident radiation in $\mathrm{mm}$ per day (Pereira et al., 1997). Meteorological data used to determine the ETo were collected with the automatic weather station Davis Vantage Pro 2 (Davis Instruments Corp., Hayward, CA, USA). The soil was maintained at field capacity with irrigation frequency of three days until the onset of treatments.

An infrared thermometer Infraterm, (Incoterm, Porto Alegre, RS, Brazil) was used to monitor leaf temperature, which was measured at $6,9,12,15$, and $18 \mathrm{~h}$ in fully developed leaves. A Scholander pressure chamber (Scholander et al., 1964) equipped with a digital manometer was used to evaluate leaf water potential, and nitrogen gas was used as a pressurizer. Top branches with about $15 \mathrm{~cm}$ were collected at 3:00 am on alternate days, and leaf tension was measured in all treatments. The water stress day index (WSDI) and the relation between the relative yield and water stress in the culture were determined by the method described by Katerji et al. (2000), using the equation $\mathrm{Y}=\mathrm{a}-(\mathrm{b} \times \mathrm{WSDI})$, in which: $\mathrm{Y}$ is the relative productivity in $\%$; a is the value of the ordinate (relative yield), which should be approximately equal to $100 ; \mathrm{b}$ is the percent loss in productivity per unit of increase in the WSDI, which is dimensionless. The WSDI was determined by the equation WSDI $=\sum_{\mathrm{i}=1}^{\mathrm{n}}\left(\psi_{\mathrm{ci}}-\psi_{\mathrm{si}}\right) / \mathrm{n}$, in which: $\psi_{\mathrm{ci}}$ is the daily leaf water potential before dawn in the control treatment over the stress period; $\psi_{\mathrm{si}}$ is the daily leaf water potential before dawn for each treatment during the stress period; $\mathrm{n}$ is the number of days with measurements. In the present study, the variable relative yield referred to essential oil content and total flavonoid content, i.e., only the levels of fresh matter (FM), dry matter (DM), and oil production were considered, since these factors may be more important in short periods of stress applied close to harvest.

After water suppression, plants from each plot were collected at $10 \mathrm{~cm}$ above ground and then sampled for determination of FM, weighed, and taken to an air forced circulation oven for determination of dry material. Moisture content of each treatment was based on DM. Essential oil was determined from 
fresh samples of about $100 \mathrm{~g}$, which were taken to a Clevenger machine and hydrodistilled during 4 hours to determine the mass of essential oil on an analytical scale. Plant material from the extraction was subjected to drying process in a forced air oven at $65^{\circ} \mathrm{C}$ until constant weight to determine DM. The oil percentage was expressed as $\mathrm{w} \mathrm{w}^{-1}$ regarding DM.

After grinding the dried material, total flavonoids were extracted from leaves according to a method adapted from Santos \& Blatt (1998). The standard curve was prepared with increasing concentrations of rutin, and expressed in $\mathrm{mg} \mathrm{g}^{-1}$. Data were subjected to mean test for comparison of the average yield of DM, FM, oil, and leaf temperature and tension among treatments, using the software SAEG (SAEG, 2007). Means were compared by Tukey's test, at $5 \%$ probability.

\section{Results and Discussion}

The highest temperatures, close to $35^{\circ} \mathrm{C}$, were observed at the beginning of the experiment (Figure 1). There was a significant decrease in temperature in the last 60 days of cultivation, in which the minimum temperatures were close to $17^{\circ} \mathrm{C}$, coinciding with the period of data collection on leaf water potential and temperature. The minimum and maximum reference evapotranspiration values were close to 2 and $7 \mathrm{~mm}$ per day, respectively, which can be attributed to the wider temperature range. There was a decrease in the evapotranspiration rate at 100 days before harvest, due to the extended rainy season of the year. The air relative humidity was relatively low in the first 40 days of cultivation, with values below $50 \%$, but was close to $70 \%$ with the start of the dry season, around April for the region.

After cultivation, the plants had the following average values: height of $1.67 \pm 0.26 \mathrm{~m}$ (mean \pm standard deviation), crown diameter of $1.07 \pm 0.29 \mathrm{~m}$, and stem diameter of $14.00 \pm 3.14 \mathrm{~mm}$. Figueiredo et al. (2009) observed heights exceeding $1.80 \mathrm{~m}$, in the same conditions, at 300 days of cultivation. Pepper-rosmarin yield, considering FM and DM, showed no significant differences between treatments, with average productivity of $8.38 \pm 0.98 \mathrm{Mg} \mathrm{ha}^{-1}$ for $\mathrm{FM}$ and $4.26 \pm 0.48 \mathrm{Mg} \mathrm{ha}^{-1}$ for DM. No differences were expected between these variables due to the short period of treatment.
Pepper-rosmarin FM yield can reach $15.96 \mathrm{Mg} \mathrm{ha}^{-1}$ under the same edaphoclimatic conditions (Figueiredo et al., 2009). According to Lopes (2010), the best irrigation depth is $1.9 \mathrm{ETo}$, with productivity of $9.59 \mathrm{Mg} \mathrm{ha}^{-1}$ for FM, with a growing period of 120 days. In the present study, the average productivity was $8.38 \mathrm{Mg} \mathrm{ha}^{-1}$ after 270 days, keeping soil at field capacity. There
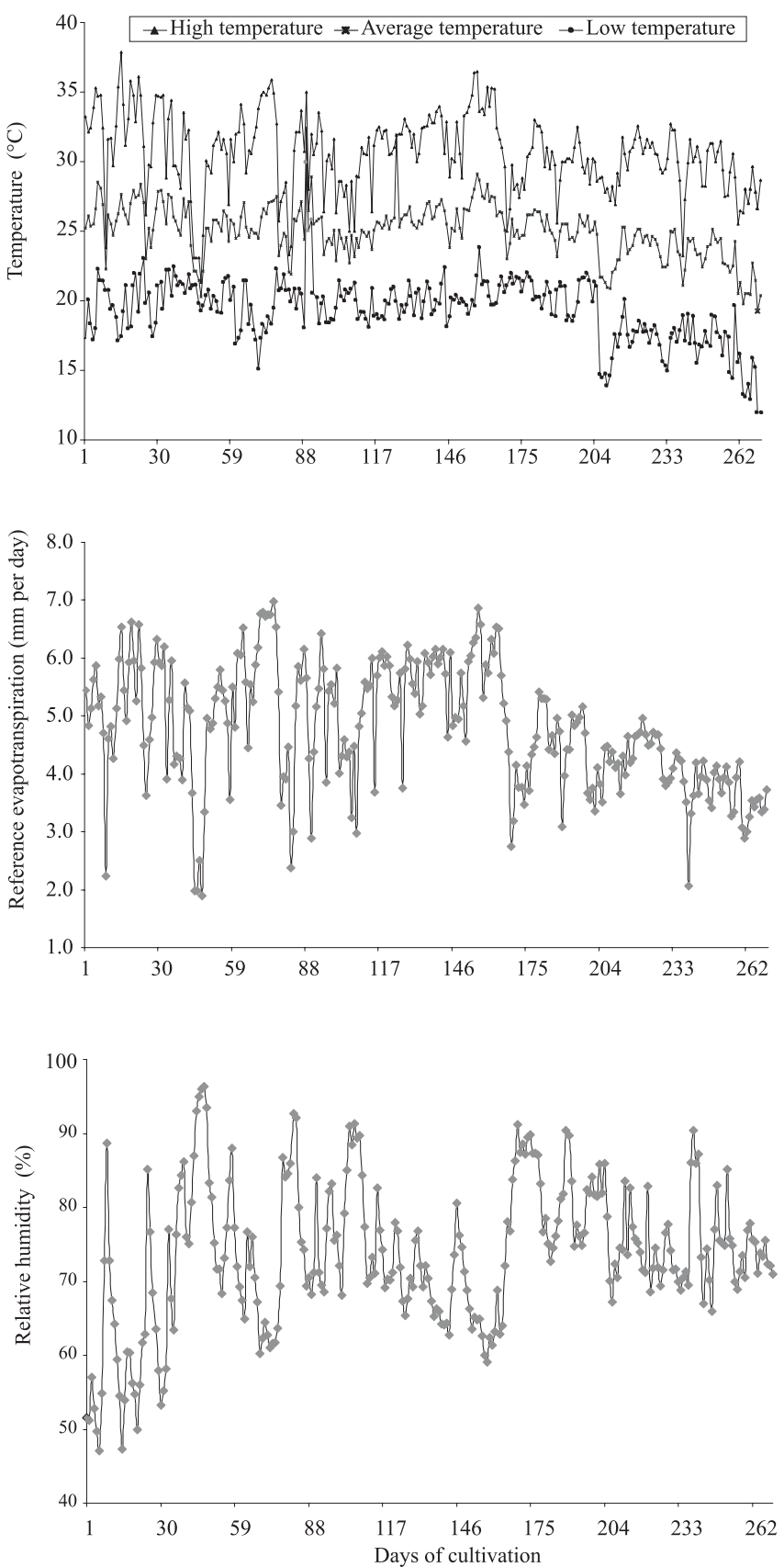

Figure 1. Oscillation temperature, evapotranspiration, and relative humidity during the crop cycle of pepper-rosmarin (Lippia sidoides). 
were no significant differences regarding essential oil production, which had an average production of $42.47 \pm 13.47 \mathrm{~kg} \mathrm{ha}^{-1}$, and moisture content, which ranged from 47.17 to $51.84 \%$.

Leaf temperature varied significantly after different periods of stress (Table 1). The highest average temperature was observed after eight days of irrigation supression, possibly due to less water availability for transpiration and, consequently, less capacity for heat exchange with the environment. In coffee plants (Coffea arabica L.), proper leaf temperatures enhance productivity, since high temperatures limit photosynthesis, causing injuries, such as leaf scald and flower abortion (Damatta, 2004). Leal et al. (2006) evaluated coffee in intercropping systems as an alternative to decrease leaf temperature, and found differences of up to $5^{\circ} \mathrm{C}$ in intercropped plants when compared to plants under sun, during the hottest hours of the day. Therefore, leaf temperature behavior regarding ambient temperature can be used as an indicator of water status in plants, which is a possible indicator for irrigation (Testi et al., 2008).

There were no significant differences among treatments for essential oil content (Table 1), which ranged from 1.27 to $0.56 \%$. Lopes (2010) observed lower values, of 0.40 and $0.60 \%$, depending on the irrigation regime. These results indicate that water suppression can be managed in order to save energy and water in the production process. Dunford \& Vasquez (2005) evaluated the influence of water stress in oregano mexicano (L. berlandieri Schauer) at different stages of plant development and found levels of essential oil ranging from 0.7 to $2.5 \%$. However, there were no significant differences among treatments, as observed in the present study. Oil composition was

Table 1. Average values of leaf water potential, temperature, and essential oil content in pepper-rosmarin (Lippia sidoides Cham.) under water stress before harvest ${ }^{(1)}$.

\begin{tabular}{lccc}
\hline Days of water stress & $\begin{array}{c}\text { Water leaf potential } \\
(\mathrm{MPa})\end{array}$ & $\begin{array}{c}\text { Leaf temperature } \\
\left({ }^{\circ} \mathrm{C}\right)\end{array}$ & $\begin{array}{c}\text { Oil content } \\
(\%)\end{array}$ \\
\hline 0 & $-0.44 \mathrm{~b}$ & $19.79 \mathrm{~b}$ & $1.17 \mathrm{ab}$ \\
2 & $-0.41 \mathrm{~b}$ & $19.53 \mathrm{~b}$ & $0.95 \mathrm{ab}$ \\
4 & $-0.47 \mathrm{~b}$ & $19.87 \mathrm{~b}$ & $0.56 \mathrm{~b}$ \\
6 & $-0.54 \mathrm{ab}$ & $19.94 \mathrm{~b}$ & $0.58 \mathrm{~b}$ \\
8 & $-0.66 \mathrm{a}$ & $21.06 \mathrm{a}$ & $1.27 \mathrm{a}$ \\
\hline $\mathrm{CV}(\%)$ & 12.27 & 26.27 & 31.10 \\
\hline
\end{tabular}

${ }^{(1)}$ Means followed by equal letters, in the columns, do not differ by Tukey's test, at $5 \%$ probability. also monitored, and no significant differences were observed for levels of thymol and carvacrol.

Total flavonoid content ranged from 0.008 to $0.0139 \mathrm{~g} \mathrm{~g}^{-1}$ regarding DM, and linearly decreased with the prolongation of water stress (Figure 2). Bortolo et al. (2009), while assessing the concentration of flavonoids in flowers and plants of marigold (Calendula officinalis L.) as affected by different irrigation depths, found no significant differences in the metabolite of flowers, although flavonoid content decreased with the increase of irrigation depth. Flavonoids are attractive to pollinators, and, as water stress accelerates the cycle of annual plants, the concentrations of the active principle increases. However, this was not observed for pepper-rosmarin.

Values for leaf water potential were relatively low, ranging from -0.41 to $-0.66 \mathrm{MPa}$ (Table 1). Nogueira et al. (2001) found values between -1 and $-5.5 \mathrm{MPa}$ after 20 days of water stress, on acerola (Malpighia emarginata D.C.) plants. Plants without water restriction or subjected to water stress may have the same leaf water

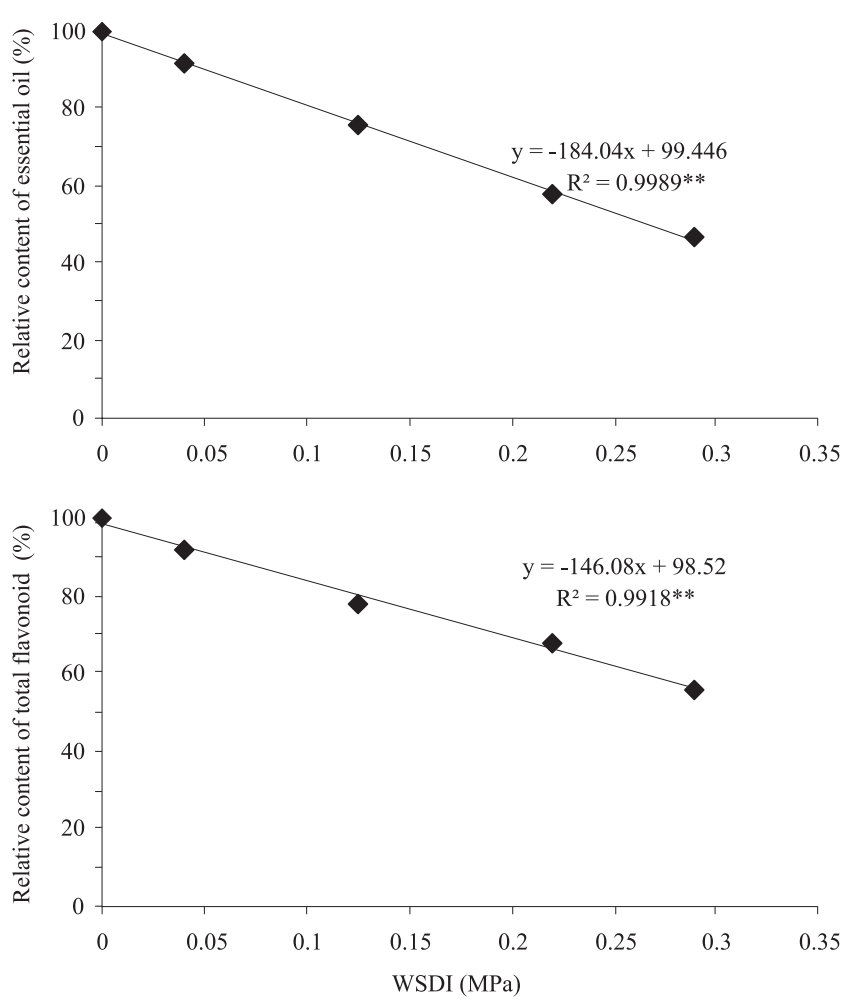

Figure 2. Essential oil and total flavonoid contents in pepper-rosmarin (Lippia sidoides Cham.) according to the water stress daily index (WSDI). ** Significant by the F test, at $1 \%$ probability. 
potential, according to the levels of water vapor loss through respiration (Schulze, 1986). In coffee, water potential ranged from -0.3 to $-0.8 \mathrm{MPa}$ for irrigated plants and from -0.6 to $-1.5 \mathrm{MPa}$ for plants under water stress (Nascimento, 2006). Pepper-rosmarin did not show great tensions in comparison to these other species, possibly due to the short period of stress.

The values found for the WSDI were also relatively low, ranging from 0.05 to $0.3 \mathrm{MPa}$, which could be related to the lower tensions observed during the experiment. Another possible explanation is that the method used to obtain the WSDI was adapted for essential oil and total flavonoid content, which have lower values in comparison to the production of FM, for example. Essential oil and total flavonoid contents decreased linearly, following the water stress magnitude, with daily decreases of approximately $50 \%$ for oil content and $60 \%$ for total flavonoids due to the reduction of $0.3 \mathrm{MPa}$ in leaf water potential (Figure 2). Oliveira et al. (2005) observed production losses of about $10 \%$ for beans, for this same range of water stress, while Garcia et al. (2009) reported values of daily water stress with production losses of nearly $25 \%$, at about $0.8 \mathrm{MPa}$. These results indicate that pepper-rosmarin plants are sensitive to water stress.

\section{Conclusions}

1. Pepper-rosmarin plants are very sensitive to water stress.

2. Water stress in pepper-rosmarin decreases essential oil content and total flavonoids up to 50 and $60 \%$, respectively, with the reduction of $0.3 \mathrm{MPa}$ in leaf water potential.

3. Essential oil from pepper-rosmarin is more sensitive to water stress than flavonoids.

\section{Acknowledgments}

To Fundo de Amparo à Pesquisa de Minas Gerais and to Conselho Nacional de Desenvolvimento Científico e Tecnológico, for financial support.

\section{References}

ALVARENGA, I.C.A.; MARTINS, E.R.; FIGUEIREDO, L.S. Alecrim-pimenta (Lippia sidoides Cham.): uma espécie aromática e medicinal em domesticação. Caderno de Ciências Agrárias, v.1, p.9-25, 2009.
ASSIS, B.F.S.; MARTINS, E.R.; SOUZA, M.F.; MELO, M.T.P.; CARVALHO JUNIOR, W.G.O. Produção de fitomassa e de óleo essencial de alecrim-pimenta em função da adubação orgânica. Revista Brasileira de Agroecologia, v.4, p.4385-4388, 2009.

BARROS, F.M.C.; ZAMBARDA, E.O.; HEINZMANN, B.M. Variabilidade sazonal e biossíntese de terpenóides presentes no óleo essencial de Lippia alba (Mill.) N. E. Brown (Verbenaceae). Química Nova, v.32, p.861-867, 2009.

BORTOLO, D.P.G.; MARQUES, P.A.A.; PACHECO, A.C. Teor e rendimento de flavonóides em calêndula (Calendula officinalis L.) cultivada com diferentes lâminas de irrigação. Revista Brasileira de Plantas Medicinais, v.11, p.435-441, 2009.

CARVALHO, A.F.U.; MELO, V.M.M.; CRAVEIRO, A.A.; MACHADO, M.I.L.; BANTIM M.B.; RABELO, E.F. Larvicidal activity of the essential oil from Lippia sidoides Cham. against Aedes aegypti L. Memórias do Instituto Oswaldo Cruz, v.98, p.569-571, 2003a.

CARVALHO, L.M. de; CASALI, V.W.D.; SOUZA, M.A. de. Soil water availability and growth of feverfew. Horticultura Brasileira, v.21, p.726-730, 2003b.

CASTRO, H.G. de; FERREIRA, F.A.; SILVA, D.J.H. da; MOSQUIM, P.R. Contribuição ao estudo das plantas medicinais: metabólitos secundários. 2.ed. Viçosa: UFV, 2004. 113p.

CHARLES, D.J.; JOLY, R.J.; SIMON, J.E. Effects of osmotic stress on the essential oil content and composition of peppermint. Phytochemistry, v.29, p.2837-2840, 1990.

DAMATTA, F.M. Ecophysiological constraints on the production of shaded and unshaded coffee: a review. Field Crops Research, v.86, p.99-114, 2004.

DUNFORD, N.T.; VAZQUEZ, R.S. Effect of water stress on plant growth and thymol and carvacrol concentrations in Mexican oregano grown under controlled conditions. Journal of Applied Horticulture, v.7, p.20-22, 2005.

FIGUEIREDO, L.S.; BONFIM, F.P.G.; SIQUEIRA, C.S.; FONSECA, M.M.; SILVA, A.H.; MARTINS, E.R. Efeito da época de colheita na produção de fitomassa e rendimento de óleo essencial de alecrim-pimenta (Lippia sidoides Cham.) Revista Brasileira de Plantas Medicinais, v.11, p.154-158, 2009.

GARCIA, G. de O.; MARTINS FILHO, S.; NAZÁRIO, A.A.; MORAES, W.B.; GONÇALVES, I.Z.; MADALÃO, J.C. Estresse hídrico e salino na produção relativa e potencial de água na folha do feijoeiro. Irriga, v.14, p.470-480, 2009.

KATERJI, N.; HOORN, J.W. van; HAMDY, A.; MASTRORILLI, M. Salt tolerance classification of crops according to soil salinity and to water stress day index. Agriculture Water Management, v.43, p.99-109, 2000.

LEAL, A.C.; CARAMORI, P.H.; ANDROCIOL FILHO, A.; PEREIRA, J. da P. Consórcio agroflorestal café $\mathbf{x}$ seringueira em Londrina (PR): efeito na produtividade e na temperatura de folhas de café. 2006. Disponível em: <http://www.iapar.br/ arquivos/File/zip_pdf/cafe $\% 20 \mathrm{e} \% 20$ seringueira.pdf $>$. Acesso em: 16 jul. 2010.

LEITE, G.L.D.; SANTOS, M.C. dos; ROCHA, S.L.; COSTA, C.A. da; ALMEIDA, C.I.M. e. Intensidade de ataque de tripes, 
de alternaria e da queima-das-pontas em cultivares de cebola. Horticultura Brasileira, v.22, p.151-153, 2004.

LOPES, O.D. Determinação do coeficiente de cultura (Kc) e eficiência do uso de água do alecrim-pimenta (Lippia sidoides Cham.) na região de Montes Claros, MG. 2010. 68p. Dissertação (Mestrado) - Universidade Estadual de Montes Claros, Janaúba.

MORAIS, L.A.S. de. Influência dos fatores abióticos na composição química dos óleos essenciais. Horticultura Brasileira, v.27, p.4050-4063, 2009. Suplemento.

MORVANT, J.K.; DOLE, J.M.; COLE, J.C. Irrigation frequency and system affect Poinsettia growth, water use, and runoff. HortScience, v.33, p.42-46, 1998.

NASCIMENTO, M.N. do. Estudo de alguns eventos do florescimento do cafeeiro relacionados a fatores do ambiente. 2006. 43p. Dissertação (Mestrado) - Universidade Federal de Lavras, Lavras.

NOGUEIRA R.J.M.C.; MORAES, J.A.P.V. de; BURITY, H.A.; BEZERRA NETO, E. Alterações na resistência à difusão de vapor das folhas e relações hídricas em aceroleiras submetidas a déficit de água. Revista Brasileira de Fisiologia Vegetal, v.13, p.75-87, 2001.

OLIVEIRA, F.G.; FERREIRA P.A.; SANTOS, D.B. dos; GARCIA, G. de O. Índice de estresse hídrico diário do feijoeiro irrigado com água salina. Revista Brasileira de Engenharia Agrícola e Ambiental, v.9, p.6-10, 2005. Suplemento.
PENKA, M. Influence of irrigation on the contents of effective substances in officinal plants. Acta Horticulturae, n.73, p.181-198, 1978.

PEREIRA, A.R.; VILLA NOVA, N.A.; SEDIYAMA, G.C. Evapotranspiração. Piracicaba: FEALQ, 1997. 183p.

SAEG: Sistema para Análises Estatísticas e Genéticas. Versão 9.1. Viçosa: UFV, 2007.

SANTOS, H.G. dos; JACOMINE, P.K.T.; ANJOS, L.H.C. dos; OLIVEIRA, V.A. de; OLIVEIRA, J.B. de; COELHO, M.R.; LUMBRERAS, J.F.; CUNHA, T.J.F. (Ed.). Sistema brasileiro de classificação de solos. 2.ed. Rio de Janeiro: Embrapa Solos, 2006. 306p.

SANTOS, M.D. dos; BLATT C.T.T. Teor de flavonóides e fenóis totais em folhas de Pyrostegia venusta Miers. de mata e de cerrado. Revista Brasileira de Botânica, v.21, p.135-140, 1998.

SCHOLANDER, P.F.; HAMMEL, H.T.; HEMMINGSEN, E.A.; BRADSTREET, E.D. Hydrostatic pressure and osmotic potential in leaves of mangroves and some other plants. Proceedings of the National Academy of Sciences of the United States of America, v.52, p.119-125, 1964.

SCHULZE, E.D. Carbon dioxide and water vapor exchange in response to drought in the atmosphere and in the soil. Annual Review of Plant Physiology, v.37, p.247-274, 1986.

TESTI, L.; GOLDHAMER, D.; INIESTA, F.; SALINAS, M. Crop water stress index is a sensitive water stress indicator in pistachio trees. Irrigation Science, v.26, p.395-405, 2008.

Received on March, 2011 and accepted on June 27, 2011 